\title{
PENINGKATAN KEMAMPUAN PEMECAHAN MASALAH DAN KOMUNIKASI MATEMATIS SISWA MTS RANTAUPRAPAT MELALUI PEMBELAJARAN KOOPERATIF TIPE STAD
}

\author{
IMPROVEMENT OF PROBLEM SOLVING ABILITIES AND MATHEMATICS \\ COMMUNICATION STUDENTS THROUGH COOPERATIVE STAD TYPE \\ LEARNING IN MTS RANTAUPRAPAT
}

\author{
ROSITA ${ }^{1}$, RIKA VALIANTI ${ }^{2}$, NURHASANAH NASUTION ${ }^{3}$, SRI HARIANI MANURUNG ${ }^{4}$ \\ ${ }^{123}$ MTs Negeri 1 Labuhanbatu, Sumatera Utara, Indonesia, \\ email: ${ }^{1}$ piliangrosita@gmail.com, ${ }^{2}$ rika22valianti@gmail.com, ${ }^{3}$ nasutionsanah @gmail.com, hㅡariani srim32@gmail.com
}

\begin{abstract}
Abstrak
Penelitian ini bertujuan mengetahui peningkatan kemampuan pemecahan masalah siswa yang memperoleh pembelajaran kooperatif tipe STAD lebih tinggi daripada kemampuan pemecahan masalah matematika siswa yang memperoleh pembelajaran secara langsung. Penelitian ini merupakan penelitian eksperimen semu (quasi experiment). Populasi dalam penelitian ini adalah seluruh siswa MTs Negeri di kabupaten Labuhanbatu yang berakreditasi A dan B. Sampel penelitian ini adalah MTs Negeri 1 Labuhanbatu dan MTs Negeri 2 berjumlah117 siswa. Validitas instrument angket dilakukan dengan analisis butir menggunakan rumus korelasi Product Moment dan uji reliabilitas menggunakan rumus Alpha Cronbach. Teknik analisis data menggunakan uji normalitas dengan uji Chi Kuadrat dan untuk menghitung peningkatan kemampuan pemecahan masalah matematika setelah pembelajaran dengan pembelajaran kooperatif tipe STAD dan pembelajaran langsung, maka digunakan uji gain ternormalisasi (g). Siswa yang mendapat model pembelajaran kooperatif tipe STAD memperoleh rata-rata peningkatan kemampuan pemecahan masalah matematis sebesar 0,63 dan siswa yang mendapat model pembelajaran langsung dengan rata-rata peningkatan kemampuan pemecahan masalah matematis sebesar 0,36 . Berdasarkan hasil analisis data penelitian diperoleh hasil bahwa ada peningkatan kemampuan pemecahan masalah siswa yang mengikuti pembelajaran koopertiftipe STAD lebih tinggi dari pada siswa yang mengikuti pembelajaran langsung.
\end{abstract}

Kata Kunci: Kooperatif Tipe STAD, Pembelajaran Secara Langsung

\begin{abstract}
This study aims to determine the increase in the problem-solving ability of students who get cooperative learning type STAD is higher than the mathematical problem solving abilities of students who receive direct learning. This research is a quasi experiment research. The population in this study were all State MTs students in Labuhanbatu district who were accredited A andB. The sample of this research is MTs Negeri 1 Labuhanbatu and MTs Negeri 2 totaling 117 students. The validity of the questionnaire instrument was carried out by analyzing items using the Product Moment correlation formula and reliability testing using the Cronbach Alpha formula. The data analysis technique used the normality test with the Chi Squared test and to calculate the increase in mathematical problem solving skills after learning with STAD cooperative learning and direct learning, the normalized gain test $(\mathrm{g})$ was used. Students who received the STAD cooperative learning model obtained an average increase in mathematical problem solving abilities of 0.63 and students who received a direct learning model with an average increase in mathematical problem solving abilities of 0.36 . Based on the results of the research data analysis, it was found that there was an increase in the problem solving ability of students who took STAD type coopertive learning higher than students who took direct learning.
\end{abstract}

Key Words: Cooperative STAD Type, Direct Learning 


\section{Pendahuluan}

Pendidikan yang berkualitas akan menghasilkan Iulusan-lulusan atau sumber daya manusia yang berkualitas begitu pun sebaliknya. Dengan adanya sumber daya manusia yang berkualitas diharapkan dapat memberikan kontribusi kepada bangsa dan Negara[1]. Kurikulum Tiga Belas mengindikasikan bahwa seorang peserta didik dapat menjadikan dirinya sebagai sumber daya manusia yang handal dan mampu berkompetensi secara global. Untuk itu dibutuhkan keterampilan yang tinggi yang melibatkan pemikiran kritis, sistimatis logis, kreatif serta mampu berkerja sama secara efektif dan efisien. Inilah kompetensi dasar yang harus dimiliki setiap individu peserta didik dimana merupakan pernyataan minimal tentang pengetahuan, keterampilan, sikap, dan nilai-nilai yang terinfeksi pada kebiasaan berpikir dan bertindak. Sebagai siswa tingkat madrasah dituntut harus menguasai bahan ajar yang disampaikan guru didalam kelas dan terampil menyelesaikan permasalahan yang diberikan khususnya pada pembelajaran matematika.

Akan tetapi pada kenyataannya, kita tidak dapat memungkiri bahwa masih banyak siswa tingkat madrasah sekarang ini yang masih menganut paradigma transfer of knowledge dalam hal mengambil keputusan dikelas, dimana interaksi dalam pembelajaran hanya terjadi satu arah yaitu dari guru sebagai sumber informasi dan siswa sebagai penerima informasi, dalam hal ini siswa tidak diberikan banyak kesempatan untuk berpartisipasi secara aktif dalam kegiatan belajar mengajar (KBM) dikelas, dengan kata lain pembelajaran lebih berpusat pada guru, bukan pada siswa. Pembelajaran matematika yang dilaksanakan dewasa ini orientasinya lebih cenderung ditujukan pada pencapaian target materi ataupun pencapaian hasil belajar.

Belajar dan Pembelajaran Belajar merupakan proses penting bagi perubahan perilaku manusia dari segala sesuatu yang diperkirakan dan dikerjakan. Belajar memegang peranan penting di dalam perkembangan, kebiasaan, sikap, keyakinan, tujuan, kepribadian, dan bahkan persepsi manusia. Oleh karena itu dengan menguasai prinsip-prinsip dasar tentang belajar, seseorang mampu memahami bahwa aktivitas belajar itu memegang peranan penting dalam proses psikologis[2].

Untuk dapat memecahkan permasalahan, tentunya seseorang harus memiliki kemampuan pemecahan masalah yang cukup. Pentingnya pemilikan kemampuan pemecahan masalah matematika pada siswa adalah bahwa kemampuan pemecahan masalah merupakan tujuan pengajaran matematika, bahkan sebagai jantungnya matematika[3]. Sedangkan dalam Kurikulum 2004 pada Depdiknas juga disebutkan bahwa tujuan pembelajaran matematika adalah untuk mengembangkan kemampuan pemecahan masalah[4]. Pemecahan masalah perlu mendapat perhatian dalam pendidikan matematika[3].

Dalam kenyataannya, masih banyak siswa yang mengalami kesulitan ketika persoalan matematika diajukan. Siswa sulit untuk mengidentifikasi konsep dan juga menerapkan konsep dalam menyelesaikan soal yang diajukan guru. Hal yang sama juga terlihat dari hasil try out ujian nasional MTs Negeri 1 Labuhanbatu yang berkerjasama dengan pusat bimbingan belajar Bumi Genesha Rantauprapat yang menunjukkan nilai rata-rata matematika 3,43 dari 158 orang siswa sedangkan standard kelulusan pada tahun 2011 adalah 5,50.

Pentingnya kemampuan pemecahan masalah dikuasai oleh siswa, sementara temuan di lapangan bahwa kemampuan tersebut masih rendah dan kebanyakan peserta didik terbiasa melakukan kegiatan belajar berupa menghafal tanpa dibarengi pengembangan memecahkan masalah. Hal sesuai dengan hasil penelitian Wahyudin yang menyimpulkan bahwa kegagalan menguasai matematika dengan baik diantaranya disebabkan siswa kurang menggunakan nalar dalam menyelesaikan masalah[5].

Pola pengajaran yang selama ini digunakan guru belum mampu membantu siswa dalam menyelesaikan soal-soal berbentuk masalah, mengaktifkan siswa dalam belajar, memotivasi siswa untuk mengemukakan ide dan pendapat mereka, dan bahkan para siswa masih enggan untuk bertanya pada guru jika mereka belum paham terhadap materi yang disajikan guru. Disamping itu juga, guru senantiasa dikejar oleh target waktu untuk menyelesaikan setiap pokok bahasan tanpa memperhatikan kompetensi yang dimiliki siswanya.

Namun dalam proses pembelajaran matematika disekolah belum sepenuhnya kemampuan pemecahan masalah matematika dikembangkan secara jelas dan tegas. Dalam kenyataannya, masih banyak siswa yang mengalami kesulitan belajar matematika. Sebelumnya, sebagian siswa menganggap mata pelajaran matematika adalah matapelajaran yang sulit, hal ini Nampak dari rendahnya prestasi belajarnya. Selain itu rendahnya prestasi belajar matematika juga dipengaruhi oleh kurangnya partisipasi aktif siswa dalam pembelajaran dikelas. Hal ini sangat menghambat siswa untuk dapat menyelesaikan permasalahan yang ada. Padahal pembelajaran matematika memiliki sumbangan yang penting untuk perkembangan hasil belajar dan pemecahan masalah dalam diri setiap individu siswa agar menjadi sumber daya manusia yang berkualitas[6]. 
Kemampuan pemecahan masalah sebagai target dalam pembelajaran matematika, siswa sering kali tidak memahami makna yang sebenarnya dari suatu permasalahan. Selain kurangnya pemecahan masalah dalam menyelesaikan masalah maka tidak sedikit para guru masih menganut paradigma bahwa pembelajaran berpusat pada guru[7]. Sejalan dengan pendapat Ruseffendi bahwa bagian terbesar dari matematika yang dipelajari siswa di sekolah tidak diperoleh melalui eksplorasi matematika, tetapi melalui pemberitahuan. Sehingga kemerosotan kemampuan pemecahan masalah siswa antara lain dikarenakan oleh cara mengajar yang dilakukan oleh guru masih menggunakan pembelajaran langsung[8]. Guru lebih menekankan pada latihan mengerjakan soal atau drill. Konsekwensi dari pola pembelajaran langsung dan latihan soal (drill), mengakibatkan siswa kurang aktif dan kurang menanamkan pemahaman konsep, dan kurang mengundang sikap kritis[3].

Perubahan paradigma lama ke paradigma baru untuk peran guru bukan lagi sebagai penyampaian informasi tetapi merupakan pemberi semangat belajar dan fasilitator, bahwa peran dan tugas guru sekarang adalah memberikan kesempatan belajar maksimal pada siswa, memberikan kebebasan berkomunikasi untuk menjelaskan idenya dan mendengarkan ide temannya. Agar hal tersebut dapat terjadi maka sebaiknya para pendidik dapat memilih, menentukan, mengembangkan model pembelajaran yang tepat dan disesuaikan dengan kemampuan matematika siswa sehingga dapat memenuhi tujuan kurikulum yang ingin dicapai[9].

Ada banyak model pembelajaran yang bisa kita gunakan dalam upayanmenumbuhkembangkan kedua kemampuan tersebut, salah satu model pembelajaran yang sejalan dengan karakteristik matematika dan harapan kurikulum yang berlaku pada saat ini sehingga dapat dilakukan pembelajaran dengan menggunakan model pembelajaran kooperatif. Model dan metode dalam pembelajaran harus mampu memotivasi siswa agar aktif dalam belajar dan juga tidak membosankan[10].

Pembelajaran kooperatif dapat membantu para siswa meningkatkan sikap positif dalam matematika. Para siswa secara individu membangun kepercayaan diri terhadap kemampuannya untuk menyelesaikan masalah-masalah matematika. Hal ini akan dapat mengurangi bahkan menghilangkan rasa cemas terhadap matematika (mathematics anxiety) yang banyak dialami para siswa. Pentingnya hubungan antar teman sebaya di dalam ruang kelas tidaklah dapat dipandang remeh. Pengaruh teman sebaya pada pembelajaran kooperatif yang ada di dalam kelas dapat digunakan untuk tujuan-tujuan positif dalam pembelajaran matematika. Para siswa menginginkan teman-teman dalam kelompoknya siap dan produktif di dalam kelas. Dorongan teman untuk mencapai prestasi akademik yang baik adalah salah satu faktor penting dari pembelajaran tersebut.

Mengingat pentingnya keberadaan teman sebaya dalam kelompok belajar yang dapat mendorong teman yang lain untuk saling aktif dan produktif di kelas, maka dipilih pembelajaran kooperatif Tipe Student Teams Achievement Divisions (STAD). Model pembelajaran kooperatif tipe STAD (Student Teams Achievement Division) merupakan model pembelajaran yang melibatkan siswa untuk saling membantu dan mendukung dalam menyelesaikan tugas sehingga mempunyai banyak kesempatan untuk mengolah informasi dan meningkatkan keterampilan berkomunikasi. Model pembelajaran STAD (Student Teams-Achievement Divisions) merupakan salah satu model pembelajaran kooperatif untuk membangun pembelajaran yang aktif[11].Pada pembelajaran kooperatif Tipe STAD, nilai kelompok merupakan nilai rerata dari nilai kuis tiap-tiap anggota. Sehingga untuk dapat memperoleh nilai kelompok yang baik, seorang siswa akan memotivasi siswa lain (satu kelompok) untuk memperoleh nilai baik. Oleh karena itu, model pembelajaran yang akan diteliti adalah pembelajaran matematika dengan strategi kooperatif Tipe STAD untuk meningkatkan kemampuan pemecahan masalah siswa.

\section{Metode Penelitian}

Penelitian ini dikategorikan kedalam penelitian eksperimen semu (quasi experiment). Rancangan penelitian yang digunakan dalam penelitian ini adalah Pretes Posttest Control Group Design. Populasi dalam penelitian ini adalah seluruh siswa MTs Negeri di kabupaten Labuhanbatu yang berakreditasi A dan B (sebanyak 8 sekolah) pada tahun 2021. Dengan acak terpilih MTs Negeri 1 Rantauprapat untuk akreditasi A dan MTs Negeri 2 Rantauprapat untuk akreditasi B sebagai sampel penelitian berjumlah 117 siswa. Tes digunakan untuk mengukur penguasaan dan kemampuan yang dicapai siswa dalam berbagai bidang pengetahuan. Instrumen yang dugunakan dalam penelitian ini adalah tes kemampuan pemecaan masalah matematika siswa. Adapun metode pengumpulan data dalam penelitian ini adalah melalui angket, observasi dan tesuraian yang disesuaikandengan kurikulum yang berlaku, dalam metode tersebut tentu disesuaikan dengan model pembelajaran penelitian yang digunakan. untuk mendapatkan data yang diperlukan dalam penelitian ini penulis menggunakan instrumen (perintah/petunjuk). Adapun angket yang digunakan untuk penelitian ini berjumlah 40 soal dan tes uraian berjumlah 5 soal tentang teorema phytagoras. 
Hal : 41-47

\section{Hasil Penelitian dan Pembahasan}

Hasil analisis deskriptif terhadap data kemampuan pemecahan masalah matematis siswa kedua kelompok pembelajaran

Tabel 1. Deskripsi Data Kemampuan Pemecahan Masalah Matematis Siswa

\begin{tabular}{|c|c|c|c|c|c|c|c|}
\hline \multirow[t]{2}{*}{ Aspek } & \multirow[t]{2}{*}{ Statis-tik } & \multicolumn{3}{|c|}{$\begin{array}{l}\text { Model pembelajaran } \\
\text { kooperatif tipe STAD }\end{array}$} & \multicolumn{3}{|c|}{$\begin{array}{c}\text { Model pembelajaran } \\
\text { Langsung }\end{array}$} \\
\hline & & Pretes & Postes & Gain & Pretes & Postes & Gain \\
\hline \multirow{2}{*}{$\begin{array}{l}\text { Memahami } \\
\text { Masalah }\end{array}$} & $\bar{X}$ & 6,018 & 8,25 & 0,73 & 6,16 & 7,64 & 0,51 \\
\hline & $S$ & 0,85 & 0,93 & 0,32 & 0,54 & 0,70 & 0,26 \\
\hline \multirow{2}{*}{$\begin{array}{l}\text { Merencanakan } \\
\text { Penyelesaian }\end{array}$} & $\bar{X}$ & 5,473 & 7,25 & 0,50 & 5,40 & 6,40 & 0,26 \\
\hline & s & 0,98 & 1,19 & 0,36 & 0,78 & 0,74 & 0,23 \\
\hline \multirow{2}{*}{$\begin{array}{l}\text { Menyelesaikan } \\
\text { Masalah }\end{array}$} & $\bar{X}$ & 4,691 & 8,13 & 0,76 & 4,95 & 7,04 & 0,46 \\
\hline & $\mathbf{S}$ & 1,59 & 1,07 & 0,29 & 1,24 & 0,90 & 0,30 \\
\hline \multirow[t]{2}{*}{$\begin{array}{l}\text { Melakukan } \\
\text { pemeriksaan }\end{array}$} & $\bar{X}$ & 2,182 & 5,87 & 0,53 & 2,38 & 4,29 & 0,28 \\
\hline & S & 1,26 & 1,76 & 0,27 & 0,85 & 1,12 & 0,18 \\
\hline \multirow{2}{*}{ Keseluruhan } & $\bar{X}$ & 18,36 & 29,62 & 0,63 & 18,89 & 25,36 & 0,37 \\
\hline & s & 2,25 & 3,59 & 0,23 & 2,18 & 2,25 & 0,16 \\
\hline
\end{tabular}

Secara umum diagram batang yang mendeskripsikan skor rata-rata pretes dan postes kemampuan pemecahan masalah pada kelas eksperimen dan kelas kontrol sebagaimana disajikan pada Gambar 1 sampai Gambar 4 berikut :

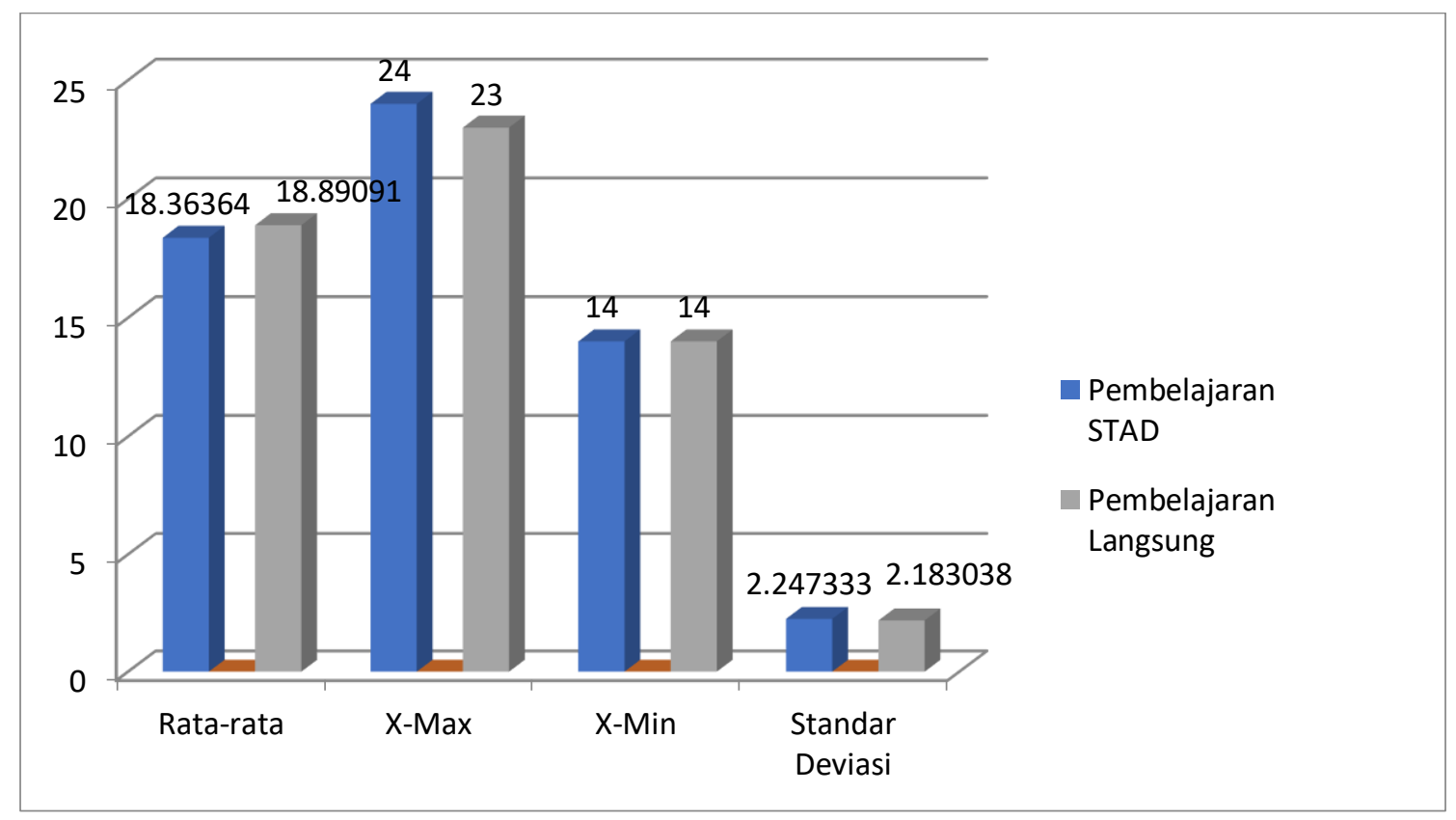

Gambar 1. Pretes Kemampuan Pemecahan Masalah Matematis Siswa 


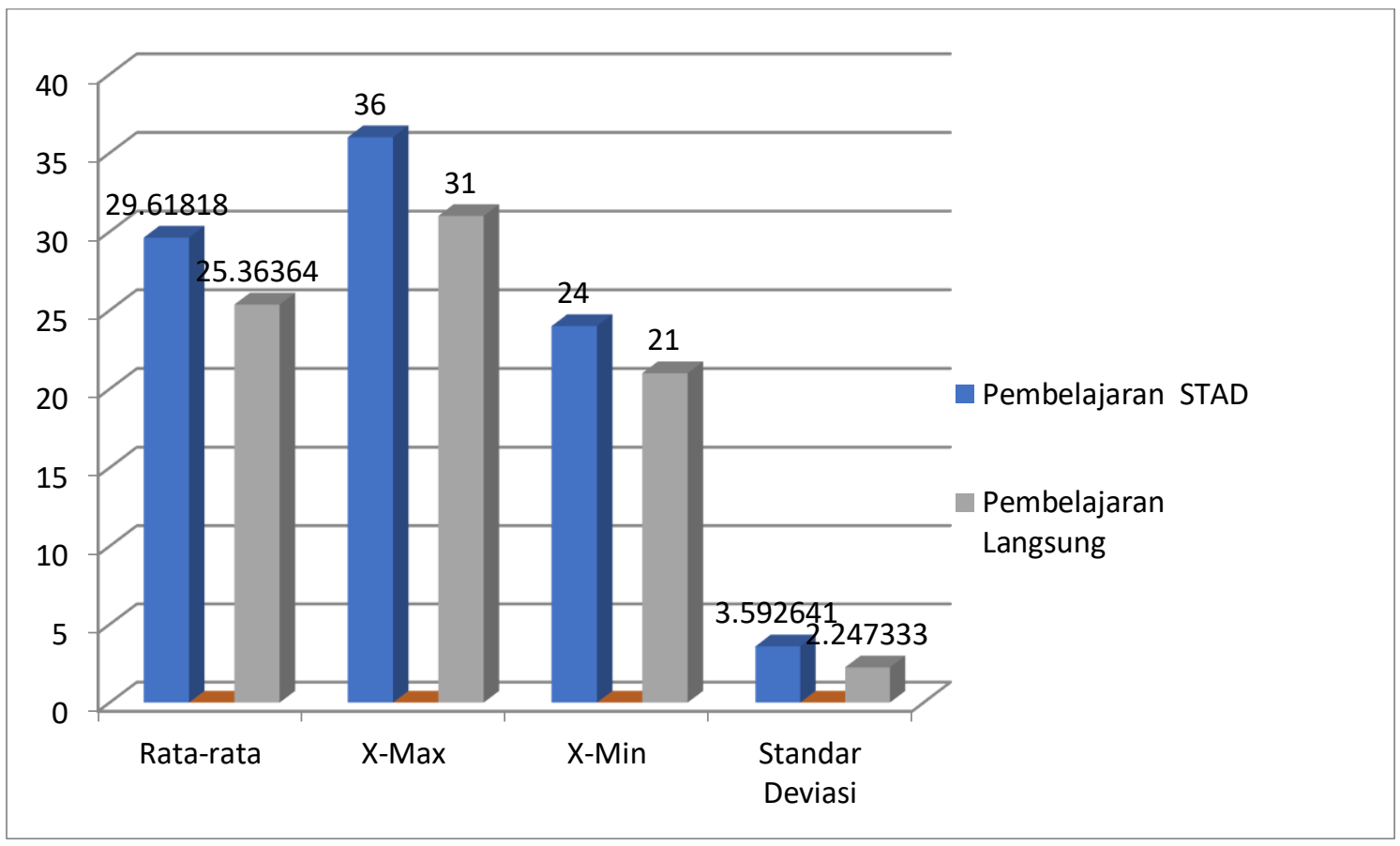

Gambar 2. Postes Kemampuan Pemecahan Masalah Matematis Siswa

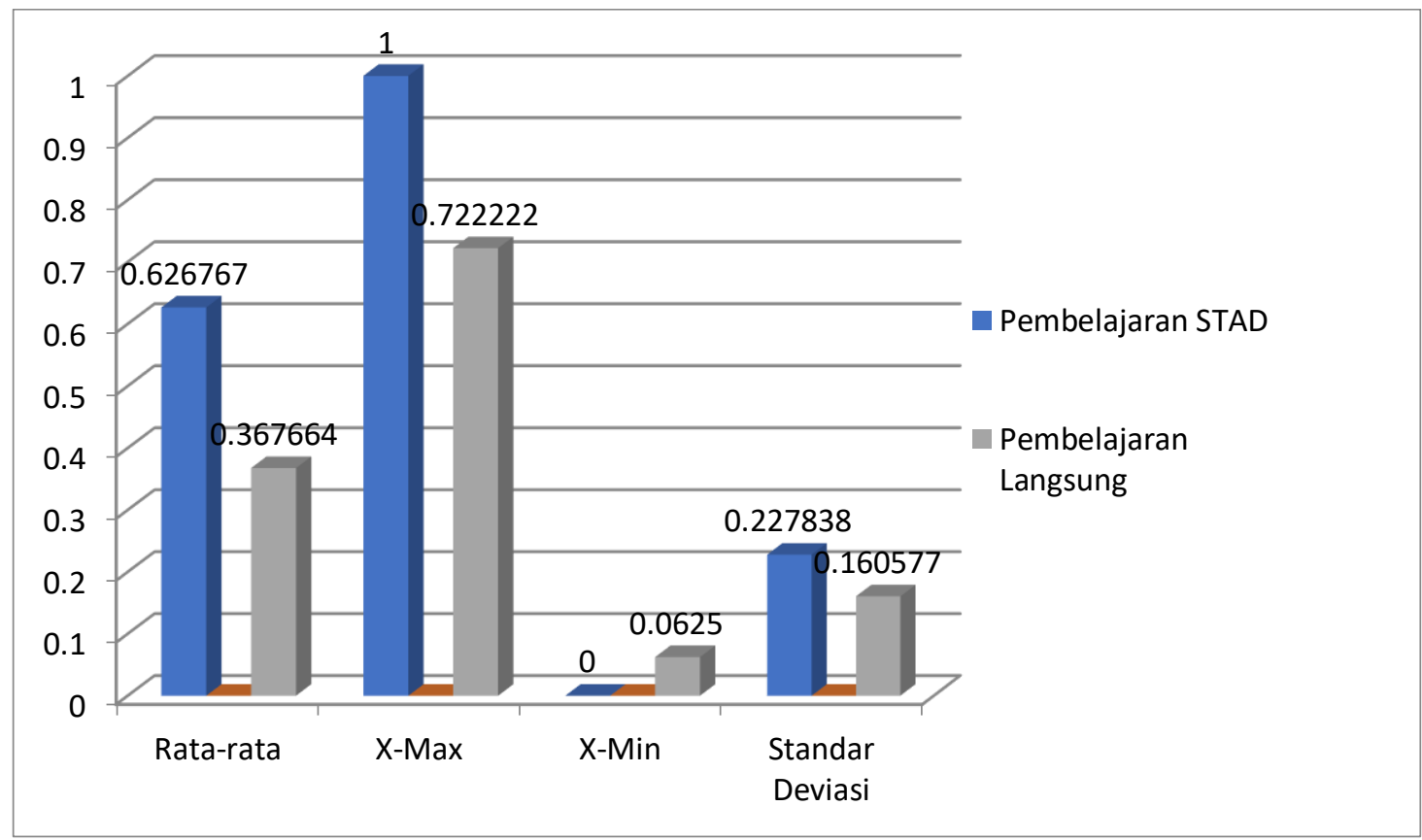

Gambar 3. Peningkatan Kemampuan Pemecahan Masalah Matematis Siswa

Secara keseluruhan gambar diagram batang dari pretes, postes, dan peningkatan kemampuan pemecahan masalah dapat dilihat dari grafik/gambar di bawah ini: 


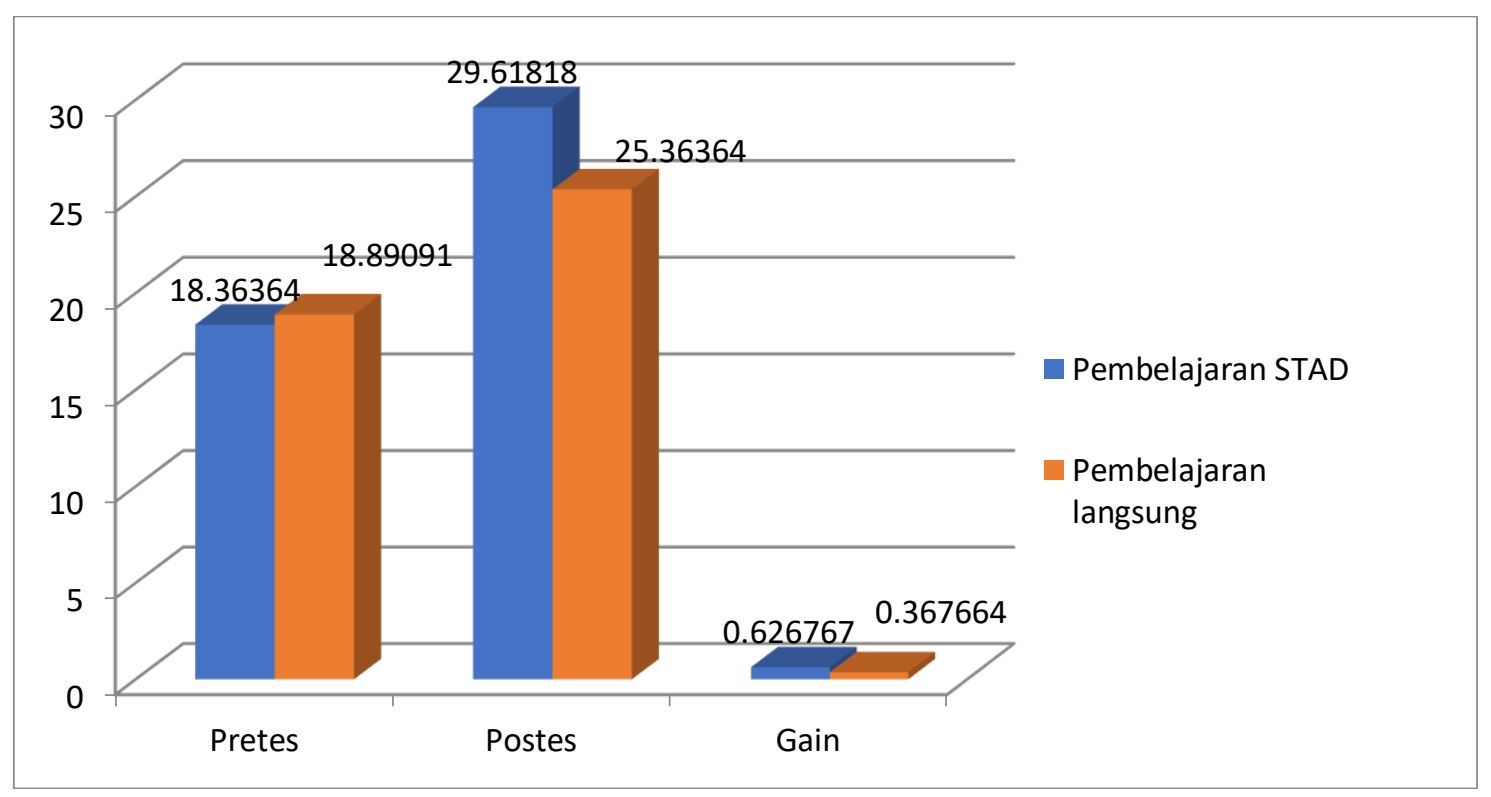

\section{Gambar 4. Pretes, Postes, dan Gain Kemampuan Pemecahan Masalah Matematis Siswa}

Berdasarakan diagram batang pretes, postes, dan gain kemampuan pemecahan masalah matematis siswa, memberikan informasi rata-rata skor pretes kemampuan pemecahan masalah matematis siswa berdasarkan model pembelajaran kooperatif tipe STAD dan model pembelajaran langsung dan berdasarkan skor rata-rata postes kemampuan pemecahan masalah matematis siswa pada model pembelajaran kooperatif tipe STAD dan model pembelajaran langsung mengalami peningkatan dari hasil pretes. Siswa pada model pembelajaran kooperatif tipe STAD dan model pembelajaran langsung mengalami peningkatan data gain kemampuan pemecahan masalah matematis.

\section{Pembahasan}

Dari penjabaran pada hasil penelitian menunjukkan bahwa kemampuan pemecahan masalah yang meliputi kemampuan memahami masalah, merencanakan penyelesaian, melaksanakan penyelesaian, dan melakukan pemeriksaan menunjukkan, pencapaian hasil kemampuan pemecahan masalah matematis siswa yang mendapat model pembelajaran kooperatif tipe STAD lebih tinggi daripada kelas yang mendapat model pembelajaran langsung.

Pada model pembelajaran kooperatif tipe STAD dan model pembelajaran langsung mengalami peningakatan gain kemampuan pemecahan masalah matematis siswa. Siswa yang mendapat model pembelajaran kooperatif tipe STAD memperoleh rata-rata peningkatan kemampuan pemecahan masalah matematis sebesar 0,63 termasuk ke dalam kategori sedang $(0,3<\mathrm{g} \leq 0,7)$ dan siswa yang mendapat model pembelajaran langsung dengan rata-rata peningkatan kemampuan pemecahan masalah matematis sebesar 0,36 termasuk ke dalam kategori sedang $(0,3<\mathrm{g} \leq 0,7)$.

Hasil penelitian menunjukkan adanya peningkatan kemampuan pemecahan masalah lebih tinggi pada kelas model pembelajaran kooperatif tipe STAD dibandingkan dengan kelas model pembelajaran langsung, hal tersebut mengindikasikan bahwa fase-fase pada model pembelajaran kooperatif tipe STAD memiliki kontribusi yang besar dalam meningkatkan kemampuan pemecahan masalah.

\section{Kesimpulan}

Berdasarkan hasil dan pembahasan penelitian selama pelaksanaan pembelajaran kooperatif tipe STAD dan pembelajaran langsung, diperoleh kesimpulan antara lain: Peningkatan kemampuan pemecahan masalah siswa yang mengikuti pembelajaran koopertif tipe STAD lebih tinggi daripada siswa yang mengikuti pembelajaran langsung. Indikator pemecahan masalah yang paling tinggi peningkatannya adalah pada aspek menyelesaikan masalah pada kelas model pembelajaran kooperatif tipe STAD, sedangkan pada model pembelajaran langsung adalah aspek memahami masalah dan aktivitas siswa selama pembelajaran menggunakan kooperatif tipe STAD termasuk dalam kategori baik.

\section{Daftar Pustaka}


Hal : $41-47$

[1] Julyanti, E. 2019. Penerapan Model Pembelajaran Snowball Throwing untuk Meningkatkan Hasil Belajar IPA Siswa di Kelas VII SMP Budi Utomo. Jurnal Pembelajaran dan Matematika Sigma (JPMS). Vol.5 No.2 hlm. 43-46 (2019)

[2] Harahap, Amin. 2017. Keefektifan Model Pembelajaran Kooperatif Tipe STAD pada Pembelajaran Matematika Pokok Bahasan Segiempat Siswa Kelas VII Semester 2 MTs Nur Ibrahimy Tahun Pelajaran 2016/2017. Jurnal Pembelajaran dan Matematika Sigma (JPMS). Vol.3 No.1 hlm. 71-75 (2017)

[3] Atun, Isrok. 2006. Pembelajaran Matematika dengan Strategi Kooperatif Tipe Student Teams Achievement Divisions untuk Meningkatkan Kemampuan Pemecahan Masalah dan Komunikasi Siswa SMA. Bandung: Tesis UPI

[4] Depdiknas 2003. Kurikulum dan Hasil BelajarKompetensi Dasar Matematika SMP dan MTs. Jakarta: Puskur-Balitbang. Depdiknas

[5] Wahyudin. (1999). Kemampuan Guru Matematika, Calon Guru Matematik dan Siswa dalam Mata Pelajaran Matematika. Disertasi Doktor pada PPs UPI Bandung: Tidak diterbitkan

[6] Yunus, M. 2015. Pengaruh Model Pembelajaran Open Ended Terhadap Hasil Belajar Matematika Siswa MTs Uswatun Hasanah Tanjung Siram. Jurnal Pembelajaran dan Matematika Sigma (JPMS). Vol.1 No.2 hlm. 40-43 (2015)

[7] Jihad, Asep. 2006. Meningkatkan Kemampuan Pemecahan Masalah Matematik Siswa dengan Metode IMPROVE disertai Embedded test (Studi Eksperimen di Madrasah Aliyah Negeri 2 Bandung). Bandung: Tesis SPs UPI.

[8] Ruseffendi, E.T. 1991. Pengantar Kepada Membantu Guru Mengembangkan Kompetensinya dalam Mengajar Matematika untuk Meningkatkan CBSA. Bandung :Tarsito

[9] Ansari, Bunsu I. 2009. Komunikasi Matematika Konsep dan Aplikasi. Banda Aceh: Yayasan Pena

[10]Siregar, SU. 2015. Pengaruh Pendekatan Belajar Tuntas Terhadap Hasil Belajar Matematika Siswa Mts Umratul Hidayah Rantauprapat. Jurnal Pembelajaran dan Matematika Sigma (JPMS). Vol.1 No.2 hlm. 37-39 (2015)

[11]Suryani. 2019. Pengaruh Model Pembelajaran Student Teams Achievement Division (STAD) terhadap Kemampuan Pemecahan Masalah Matematika. Jurnal Pembelajaran dan Matematika Sigma (JPMS). Vol. 5, No. 1 (2019) hal.1-6 